\title{
Implications of selected approaches for regenerating and managing western boreal mixedwoods
}

\author{
by Philip G. Comeau1, Richard Kabzems², John McClarnon³ and Jean L. Heineman ${ }^{4}$
}

\begin{abstract}
We describe a range of approaches for managing boreal mixedwood stands composed of trembling aspen (Populus tremuloides Michx.) and white spruce (Picea glauca (Moench) Voss) in British Columbia and Alberta. Successful management of these complex forests requires a combination of well-defined objectives at the landscape level and flexible planning at the stand level. A variety of management strategies must be applied concurrently across the landscape to ensure that the natural mix of forest types and structural diversity is maintained. Selected approaches are discussed with regard to their suitability to particular stand conditions and sets of objectives, the types of tending and harvesting activities required, expected outcomes, and costs. The three approaches discussed are: 1) creation and management of two-storied intimate mixtures; 2) creation of a single-storied mixture of aspen and white spruce; and, 3) creation of a mosaic of discrete patches of each species.
\end{abstract}

Key words: boreal mixedwood management, mixedwood silvicultural systems, aspen, white spruce, planning

\section{RÉSUMÉ}

Cet article décrit quelques approches en matière d'aménagement des peuplements mélangés de la forêt boréale composés de peuplier faux-tremble (Populus tremuloides Michx.) et d'épinette blanche (Picea glauca (Moench) Voss) en ColombieBritannique et en Alberta. La réussite de l'aménagement de ces forêts complexes nécessite une combinaison d'objectifs bien définis au niveau de l'écosystème ainsi qu'une planification flexible au niveau du peuplement. Plusieurs stratégies d'aménagement doivent être utilisées simultanément au sein de l'écosystème afin d'assurer le maintien du mélange naturel des types de forêt et de la diversité structurelle. Certaines approches sont abordées en fonction de leur pertinence relativement à certaines conditions de peuplement et d'ensembles d'objectifs, des mesures d'entretien et des activités de récolte requises, des retombées envisagées et des coûts. Les trois approches discutées porte sur 1) la création et l'aménagement de peuplements intimement mélangés à deux étages, 2) la création d'un peuplement mélangé à un seul étage de tremble et d'épinette blanche et 3 ) la création d'une mosaïque de blocs individuels de chacune des espèces.

Mots clés : aménagement des peuplements mélangés de la forêt boréale, régimes sylvicoles des peuplements mélangés, tremble, épinette blanche, planification

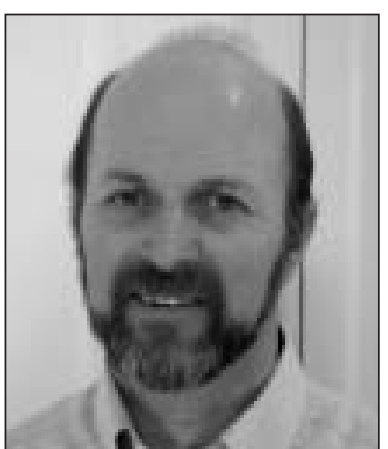

Philip G. Comeau

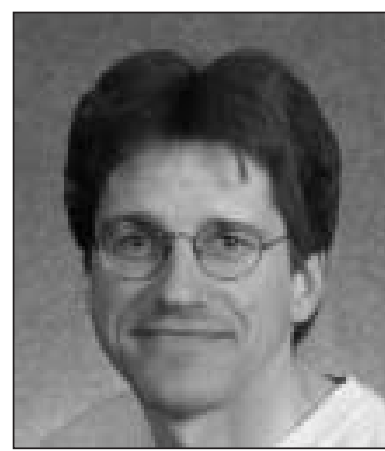

Richard Kabzems

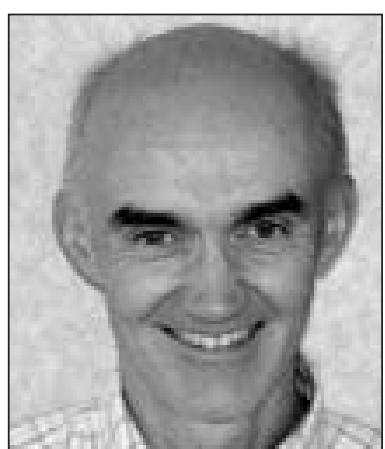

John McClarnon

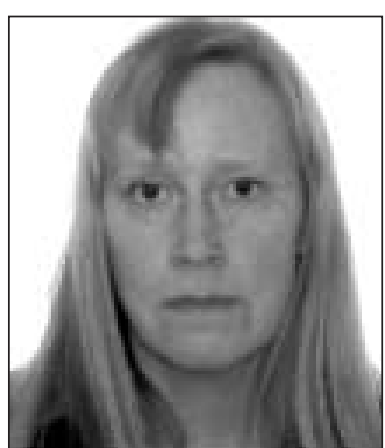

Jean L. Heineman

\footnotetext{
${ }^{1}$ Centre for Enhanced Forest Management, Dept. of Renewable Resources, 442 Earth Sciences Building, University of Alberta, Edmonton, Alberta T6G 2E3. E-mail: Phil.Comeau@afhe.ualberta.ca (Corresponding author)

${ }^{2}$ B.C. Ministry of Forests, 9000 17th St., Dawson Creek, British Columbia V1G 4A4.

${ }^{3}$ B.C. Ministry of Forests, 9th Floor - 727 Fisgard St., Victoria, British Columbia V8W 1R8.

${ }^{4}$ J. Heineman Forestry Consulting, 2125 E. 5th Ave., Vancouver, British Columbia V5N 1M5.
} 


\section{Introduction}

New approaches are needed to successfully manage boreal mixedwood forests in British Columbia and Alberta on both ecologically and economically sound principles. Relatively little attention has traditionally been paid to these forests because of their low commercial value in comparison with other forest types; however, they are now the subject of intense interest. Andison and Kimmins (1999) cite three main reasons for the change in focus: 1 ) new wood processing technology is increasing our ability to utilize broadleaf species; 2 ) depletion of timber reserves in other regions has rendered the boreal forest of greater interest; and 3) the need for ecologically based management strategies has been recognized on a worldwide basis.

Mixedwood stands are a prominent component in many parts of Canada's boreal forest. In British Columbia and Alberta, these stands are comprised primarily of mixtures of trembling aspen (Populus tremuloides Michx.) and white spruce (Picea glauca (Moench) Voss), with a minor component of balsam poplar (Populus balsamifera L.) (Rowe 1972, DeLong et al. 1990). Western boreal mixedwood forests lack the abundant advance regeneration of balsam fir (Abies balsamea (L.) Mill.) that exists in their eastern counterparts (Greene et al. 2002). Forest composition is similar across boreal regions of British Columbia and Alberta, with subtle differences reflecting patterns of precipitation, elevation, and temperature (DeLong et al. 1990, Beckingham and Archibald 1996).

Mixedwood forests represent a range of early- to mid-seral successional stages (Chen and Popadiouk 2002). Following disturbance, mixedwoods develop most commonly on mesic sites (Lieffers et al. 1996) where successional pathways are less predictable than on dry or wet sites (Andison and Kimmins 1999). When aspen and white spruce regenerate at approximately the same time following disturbance, aspen will form an overstory above spruce, except in gaps, for at least 50 to 60 years. After that time, white spruce begins to grow through the canopy as aspen decreases in dominance and basal area. Eventually, in the absence of fire, wind, harvesting, or other large-scale disturbance, the mixedwood stand may become a spruce-dominated stand (Chen and Popadiouk 2002). White spruce may also establish naturally in the understory of mature aspen stands (e.g., Kabzems and Garcia 2004). Light levels under fully stocked boreal mixedwood stands reach minimum levels between 10 and 25 years after disturbance (Lieffers et al. 2002), but increase to 15-20\% of full sunlight or higher at around age 40, which is adequate to allow establishment of white spruce (Groot et al. 1997, Comeau 2002).

There are a number of advantages to managing mixedwoods as such rather than attempting to convert them to pure white spruce or aspen stands. Mixedwoods support sustainable management objectives such as preserving species and structural diversity, protecting wildlife habitat and food, and preserving visual aesthetics (e.g., Peterson and Peterson 1995, Comeau 1996). Long-term site productivity is also enhanced by the presence of aspen, which takes up large amounts of nutrients and retains them within the system (Pastor 1990). The risk of attack by white pine weevil (Pissodes strobi Peck) (Stiell and Berry 1985, Alfaro 1996, Taylor et al. 1996) and, in eastern Canada, spruce budworm (Choristoneura spp.) (MacLean 1996, Su et al. 1996) is lower in mixedwood than pure conifer stands. Despite this, anecdotal evidence from the boreal region of western Canada suggests that the spruce budworm can substantially reduce spruce productivity even in mixedwood stands. The risk of Armillaria root disease is also lower in mixedwood than pure conifer stands (Morrison et al. 1991, Gerlach et al. 1997). Finally, overstory aspen is an effective nurse crop for understory spruce because it reduces the incidence of growing season frost by providing protection from environmental extremes (Groot and Carlson 1996, Pritchard and Comeau 2004). The overstory also reduces the vigour of understory competitors such as bluejoint (Calamagrostis canadensis (Michx.) Beauv.) and other species (Lieffers and Stadt 1994, Constabel and Lieffers 1996, Groot and Carlson 1996, Groot 1999, Comeau et al. 2004).

In addition to the biological advantages, economic benefits can also be derived by managing mixedwoods that, historically, have been underutilized in favour of more valuable pure conifer stands. Mixedwoods are currently increasing in value because they are a good source of high-quality fibre, because markets for aspen are expanding, and because they can potentially provide greater diversity of products than single-species stands (MacDonald 1996). White spruce is expensive and difficult to establish in pure stands following disturbance (Lieffers et al. 1996, MacDonald 1996), whereas mixedwoods may be easier to establish and may even produce higher quality spruce stems than result from more open growing conditions (Anon. 2000). Finally, overall yield from mixedwood stands may be higher than from single-species stands because of the physical, phenological, and successional differences in growth strategy that exist between aspen and white spruce (Man and Lieffers 1999, MacPherson et al. 2001).

Despite the current interest in mixedwood management, practical experience in the western boreal is limited. A scientifically defensible and credible mixedwood strategy must include management objectives that are appropriate at both the landscape and stand levels, and it must also ensure that suitable silvicultural systems are selected for these highly complex stands. Policies should allow flexibility in decisionmaking at the individual stand level as long as overall landscape-level objectives are met. Landscape-level objectives should seek to maintain the natural mix of forest types in order to maintain health and sustainability at the ecosystem level, sustained yield, and long-term economic and ecological benefits. At the stand level, objectives are more likely to be concerned with mixture ratio, yield, stand structure, and budget. In order to meet the objective of maintaining the natural complexity of mixedwood forests, a variety of stand-level management approaches should be employed across the landscape. To be effective, government policy and regulations should support this process.

The objective of this article is to compare a selected set of promising silvicultural systems and stand tending options for application in western boreal mixedwood forests. Some of the approaches have been previously discussed with regard to Alberta mixedwoods (e.g., Navratil et al. 1994, Lieffers et al. 1996, Lieffers et al. 2003), while others have been developed through discussions among researchers, policy makers, and practitioners in north-eastern British Columbia and Alberta. The options range from a low-intensity "do-nothing" approach that accepts the natural stratification of spruce and aspen, to intensive management aimed at optimizing white 
spruce yield within a mixedwood context. We emphasize that the strategies are not presented as either/or options, but rather as a set of options that can be applied as appropriate across the landscape.

\section{Management Approaches}

In this section, strategies for managing mixedwoods are discussed under three general headings, depending on whether the desired stand structure is 1) an intimate mixture (i.e., a mixture with a more-or-less horizontally homogeneous distribution of spruce and aspen) that develops into two stories that are suitable for two-stage harvesting, 2) an intimate mixture that develops into a single story of co-dominants that is suitable for one-stage harvesting, or 3) a mosaic of discrete, single-species groupings that are suitable for one- or twostage harvesting. Information regarding appropriate stand conditions, appropriate objectives, management considerations, and tending and harvesting requirements with associated costs are summarized for the various mixedwood management approaches in Table 1.

\section{Approach 1: Successional management of two-story intimate mixtures}

Successional management means allowing intimate mixtures of aspen and white spruce to develop naturally following the natural or artificial establishment of white spruce and natural regeneration of aspen after a disturbance such as fire or clearcut harvesting. Due to differences in growth rate and shade tolerance between aspen and white spruce, aspen soon forms an overstory over the slower-growing spruce. This is a non-intensive approach that is suitable for sites that are inaccessible or not highly productive. Costs are low, particularly where spruce has regenerated naturally on the site, but because aspen densities (and hence light levels) are accepted as they occur, spruce performance is likely to be slow to moderate, and the spruce rotation relatively long. Successional management sets the scene for a two-stage harvesting approach where, in the first stage, aspen are harvested at biological maturity to release understory spruce. Aspen suckers fill in any gaps not occupied by spruce, and contribute to yield when spruce are harvested in the second stage. Spruce will respond to removal of the aspen canopy as long as they are physiologically capable of release (Ruel et al. 2000). Rotation length and white spruce volume at the second harvest will depend on site characteristics and the condition and density of spruce at the time of release. Successional management can be undertaken immediately following disturbance or at aspen mid- rotation (Fig. 1).

This approach emulates natural successional processes and maintains tree cover within harvested blocks. In general, it works towards maintaining mixedwood stands, although it may result in shifts in the relative dominance of aspen and white spruce in the stands.

\section{Regeneration options for two-story mixtures}

On sites where natural regeneration of white spruce has been satisfactory, no further activities are required. However, successful natural regeneration depends on a range of factors that include proximity to a seed source, seedbed characteristics, and the absence of seed predators (Galipeau et al. 1997, Smith et al. 1997, Greene et al. 1999, Côté et al. 2003). On some sites, it may be necessary to plant or seed to attain the desired density of established spruce. Artificial regeneration adds to the cost of successional management, especially if site preparation and brushing treatments are required.

\section{Planting}

White spruce can be planted immediately following disturbance or underplanted below the aspen canopy 10 to 20 years prior to the planned harvest date for aspen (Lieffers et al. 1996).

\section{Planting immediately after disturbance}

Planting white spruce immediately after disturbance has the advantage of being a familiar, easy-to-administer, relatively low-cost practice. After planting, no further treatments are applied. However, site preparation may be necessary to establish seedlings; mechanical treatments such as mounding can provide well-spaced planting microsites to ensure good early survival and performance of white spruce.

\section{Underplanting}

There are a number of advantages to underplanting if stand conditions are appropriate. Brushing treatments are unlikely to be necessary to establish underplanted seedlings because the relatively low light availability beneath the aspen canopy inhibits development of shrubs, forbs and grasses (Lieffers and Stadt 1994). Overstory aspen also protect understory white spruce seedlings from environmental extremes (Stathers 1989, Groot and Carlson 1996, Krasowski 1996), pests (e.g., Taylor et al. 1996), and root disease (Gerlach et al. 1997).

Underplanting is a cost-effective method for regenerating white spruce in western boreal mixedwood stands, although only a minor portion of the landbase (e.g., 30\%, Greene et al. 2002) may be suitable. Aspen stands that are good candidates for underplanting have canopies that are dense enough to restrict growth of understory vegetation, but that allow adequate light availability for acceptable survival and early growth of white spruce. At least 15\% light availability is required if three-year survival of white spruce is to reach $80 \%$ (Kobe and Coates 1997). Greene et al. (2002) recommend that light availability should be greater than $25 \%$ for underplanting to succeed. Light availability beneath aspen canopies is at a minimum when stands are 10 to 25 years old (Lieffers et al. 2002), but is approximately $18-30 \%$ by age 40 years (Groot et al. 1997, Comeau 2002). DeLong (1997) used the following criteria to define stand suitability for underplanting: a) aspen should be 30-60 years old, b) maximum density should be 1200 stems/ha, and c) maximum basal area should be $35 \mathrm{~m}^{2} /$ ha. A recent study suggests that underplanting may be successful even when aspen basal area approaches 51 $\mathrm{m}^{2} /$ ha and stand density exceeds 3000 stems/ha (Comeau et al. 2004). Light availability prior to aspen leaf-out may be sufficient to enable adequate spruce height growth for creation of a two-story mixture (Constabel and Lieffers 1996).

Although site preparation under mature aspen canopies is possible, sites where herbaceous and/or low shrub vegetation is abundant enough to require these treatments are generally considered to be unsuitable for underplanting. Neither mechanical (Stewart et al. 2000) nor chemical treatments (Groot 1999) improved survival or height growth of under- 


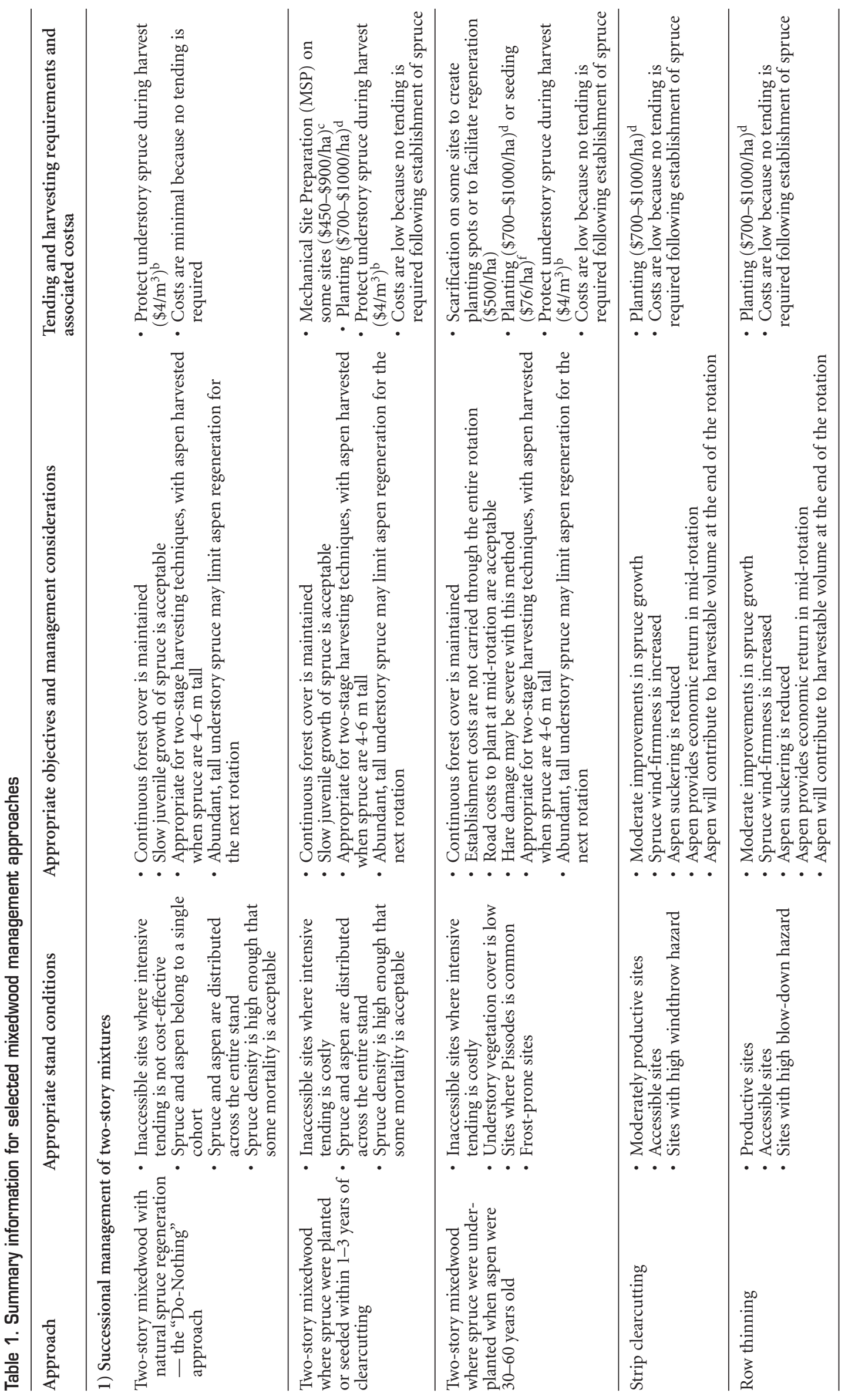




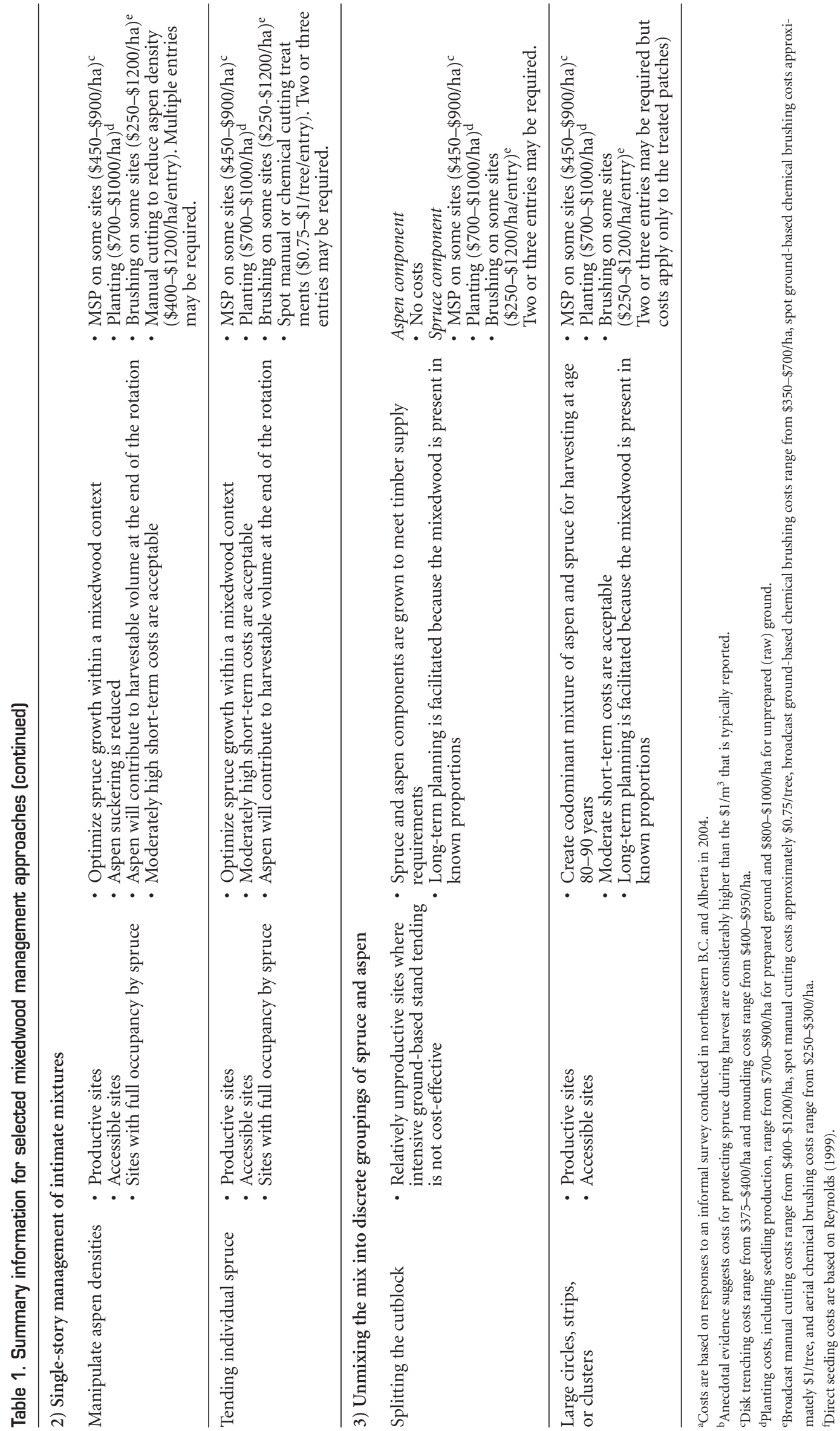




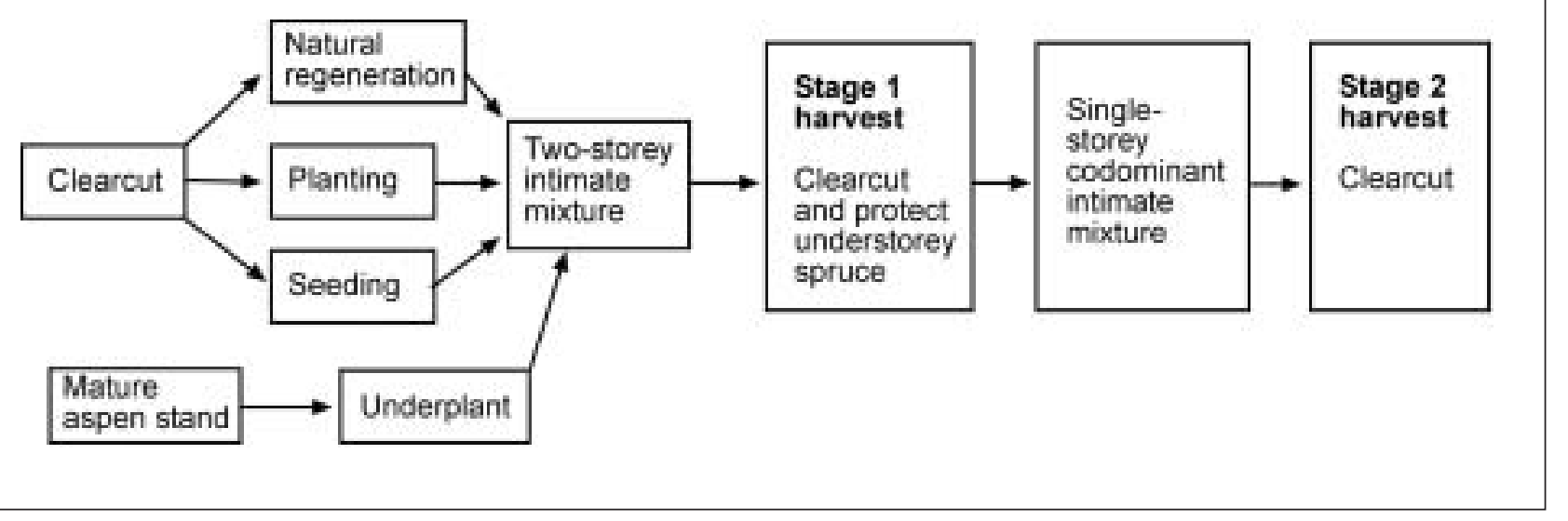

Fig. 1. Schematic diagram of the activities involved in successional management of two-story intimate mixtures.

planted white spruce, although scarification did increase early diameter growth. Site preparation treatments add to costs and aspen can easily be damaged by machinery. Mechanical damage to aspen roots may also increase their susceptibility to Armillaria root disease (Pankuch et al. 2003), which increases the likelihood that spruce also will become infected. Raw planting (i.e., planting into unprepared ground) works well for underplanting as long as adequate light and moisture are available and understory vegetation competition is not excessive.

The potential for snowshoe hare (Lepus americanus) damage is also a consideration in underplanted stands (DeLong 2000). Regular browsing can compound the reduced growth rates that spruce exhibit in low-light understory environments. The risk of hare damage can be minimized by a) not planting when the hare cycle is on the increase (populations fluctuate on an approximately 10-year cycle), and (b) avoiding planting in close proximity to recently disturbed areas (Radvanyi 1987). Planting bareroot seedlings that have not been treated with a final dose of fertilizer may also reduce the palatability of newly planted spruce seedlings to hares (Greene et al. 2002).

\section{Seeding}

Regeneration by natural or artificial seeding is an accepted operational method in eastern boreal forests, but less so in the west (Greene et al. 1999, Greene et al. 2002). In British Columbia and Alberta, direct seeding has always been a less popular regeneration option for white spruce than planting because a) results are less reliable (Coates et al. 1994), b) good quality white spruce seed is expensive to obtain, c) a high level of monitoring and coordination of activities is required for successful implementation, d) the smaller stature of germinants compared with planted seedlings increases the risk of mortality from vegetation and other damaging agents (Coates et al. 1994), and e) establishment by seeding may also increase the time required for spruce to reach a harvestable size (Coates et al. 1994). In interior Alaska, natural and artificial regeneration from seed has been highly successful for establishing white spruce on sites that were burned by wildfire and then scarified, although after 10 years, seeded spruce were only about one-third as tall as planted spruce (Densmore et al. 1999).
The possible disadvantages of seeding notwithstanding, seedbed creation is possible on either newly disturbed areas or in the aspen understory. However, Greene et al. (2002) advise that seeding is an inappropriate technique on any site where there may be significant occupation by bluejoint. Seedbeds created by mixing, screefing, and mounding have resulted in successful establishment of hand-seeded white spruce beneath aspen canopies, but establishment rates have averaged $7 \%$ to $15 \%$ of seed sown (DeLong et al. 1997, Stewart et al. 2000). Scarification is also effective for promoting natural regeneration on newly disturbed sites, although seed rain events were found to be unpredictable (Stewart et al. 2000) and good seedbeds can be rapidly invaded by other vegetation.

\section{Harvesting options for two-story mixtures}

There are several harvesting approaches that can be applied to two-story mixtures, but the most appropriate option will largely be dictated by the risk of windthrow. Wet sites are at higher risk than mesic sites, and stands where white spruce are taller than $7 \mathrm{~m}$ and have a slenderness coefficient (e.g., height:diameter ratio) exceeding 100 are at higher risk than those where spruce are shorter (Navratil 1996).

If a two-stage harvesting approach is considered, understory white spruce should be of adequate density and condition to eventually yield sufficient merchantable volume to justify the additional planning and harvesting costs. According to Ruel et al. (2000), white spruce is physiologically capable of release when it has minimum height growth of $10 \mathrm{~cm} /$ year, an apical dominance ratio of $1,60 \%$ live crown, and a minimum of four nodal branches and three internodal branches. Potential spruce losses during aspen harvest must also be considered because, even with good understory protection, up to half the spruce stems may be lost (Navratil 1996), although typical losses range from $10 \%$ to $20 \%$ away from roads and processing areas. The most suitable stands are those that are capable of producing a significant, and perhaps dominant, white spruce component at the final (second stage) harvest. As a general guideline, low suitability stands have less than 400 healthy spruce stems/ha prior to harvest. If a stand has been slated for successional management but does not support sufficient understory spruce regeneration, 


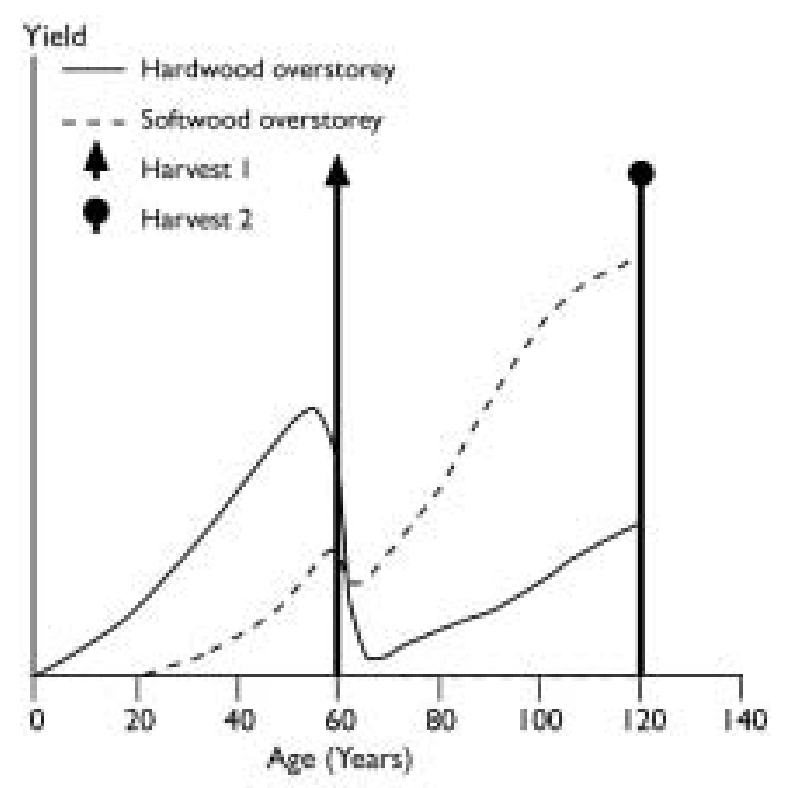

Generalized two-stage harvesting and tending model (from Brace and Bella 1988).

Fig. 2. Relative yields of white spruce and aspen using a uniform two-stage harvesting approach (from Brace and Bella 1988).

it may be appropriate to manage the site for pure aspen in exchange for a site that is a better candidate for mixedwood management.

\section{Uniform two-stage harvesting}

Uniform two-stage harvesting, which is based on a model developed by Brace and Bella (1988), involves complete harvest of the aspen overstory to release understory white spruce (Fig. 2). Spruce are protected during the aspen harvest and are harvested when they reach maturity. Both the FORECAST model (Welham et al. 2002) and MGM (Bokalo 2005) suggest that this approach can provide higher total yields than conventional, single-pass harvest methods.

A uniform two-stage harvesting approach is appropriate where the risk of windthrow is not excessively high. Spruce should be between 4 and $6 \mathrm{~m}$ tall when the aspen canopy is removed to accommodate the need for both windfirmness and release from surrounding vegetation. Minimum heights of $2.5 \mathrm{~m}$ (Johnson 1986) and $3.5 \mathrm{~m}$ (Yang 1989) have previously been suggested for spruce at the time of release, and a recent study from Ontario has recommended that conifers should be at least $4 \mathrm{~m}$ tall if they are to remain above broadleaf and shrub regeneration (MacDonald et al. 2004).

Protection of advance spruce regeneration during aspen harvest is a critical factor for successful two-stage harvesting. Conventional logging equipment such as feller-bunchers and grapple skidders can be used successfully as long as the fellerbuncher has the ability to cut and place stems on skid trails without damaging retained spruce and the grapple skidders only travel on designated skid trails (Brace 1991). Regardless of equipment used, however, planning, layout, supervision, crew training and experience are of critical importance (Brace 1991, Navratil et al. 1994).

\section{Two-stage strip shelterwood}

Strip shelterwood silvicultural systems can be applied in several ways (Smith et al. 1997). They are suitable for boreal mixedwoods because of their compatibility with modern harvesting equipment and because they provide wind protection to understory conifers following removal of the aspen overstory (Navratil et al. 1994, Flesch and Wilson 1999). The method we describe is appropriate where spruce exceeds $6 \mathrm{~m}$ in height and would be susceptible to windthrow following complete removal of the aspen canopy. Aspen are removed in strips to release previously established understory spruce or advance spruce regeneration. Once spruce reach merchantable size, they are harvested in the second stage, along with any merchantable aspen. Harvesting begins when spruce are $4-12 \mathrm{~m}$ tall, and the aspen is merchantable.

Unharvested wind buffers are retained every $50 \mathrm{~m}$ or less within the stand, with the strips oriented in a direction that is perpendicular to the predominant wind direction (Anon. 2003). Skid trails (4-6 m wide) are designated within the harvested area, at a spacing that is twice the reach of the feller buncher to be used (i.e., with a machine reach of $8 \mathrm{~m}$, skid trails occur at 16-m intervals). To start, aspen on the designated skid trail are completely harvested by the feller-buncher and skidded from the trail. The feller-buncher then makes a second harvesting pass along the trail, cutting aspen stems to either side and placing them on the trail for skidding. This sequence of strips, which is repeated across the harvested area, results in three types of spruce-aspen composition: a) the designated skid trails regenerate to aspen, b) the $16-\mathrm{m}$ wide partially harvested strips become dominated by spruce, and c) the windbreak strips remain as two-story mixtures of aspen and understory spruce (Fig. 3).

On sites that are at extremely high risk of windthrow, a three-stage method is possible, although it is not usually economically practical due to the high cost of an additional stand entry. In the three-stage method, $50 \%$ of aspen volume is harvested in the first pass, the remaining 50\% is harvested 10 years later in a second pass, and spruce are harvested at maturity in the third pass.

\section{Two-stage group and uniform shelterwoods}

Two-stage group and uniform shelterwood methods are used to some extent in Ontario (Anon. 2003). Smith et al. (1997) describe the group shelterwood method as arranging individual species in discrete groups; in Ontario, this is achieved by progressively removing aspen in small gaps, the size of which will depend on stand objectives and the stature of understory spruce. Kabzems (2001) found light availability in large (1.0 ha) gaps was generally above $60 \%$, which is ideal for spruce growth, but which also stimulates growth of shrubs and aspen regeneration. Light levels in small $(0.13 \mathrm{ha})$ gaps did not exceed $15 \%$, which is sub-optimal for spruce growth, but which prevented large increases in cover of shrubs and aspen regeneration.

The uniform shelterwood method is described as retaining trees (e.g., aspen) in an even distribution across the harvested area (Smith et al. 1997). Uniform shelterwood systems have been used experimentally in the Prairie Provinces (Lees 1964, Waldron and Kolabinski 1994) and interior Alaska 


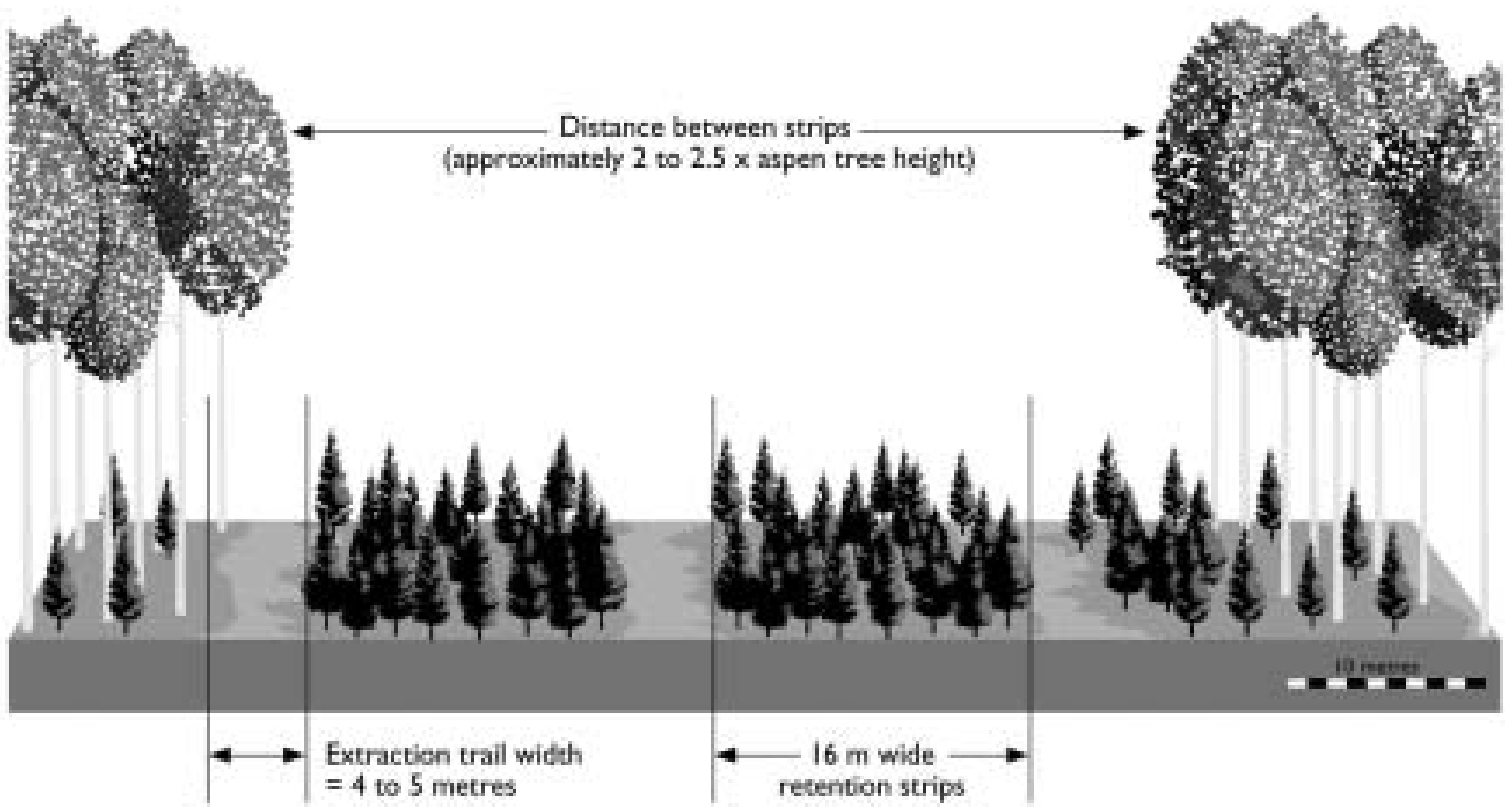

Fig. 3. An example of the two-stage strip shelterwood method after the first harvesting stage.

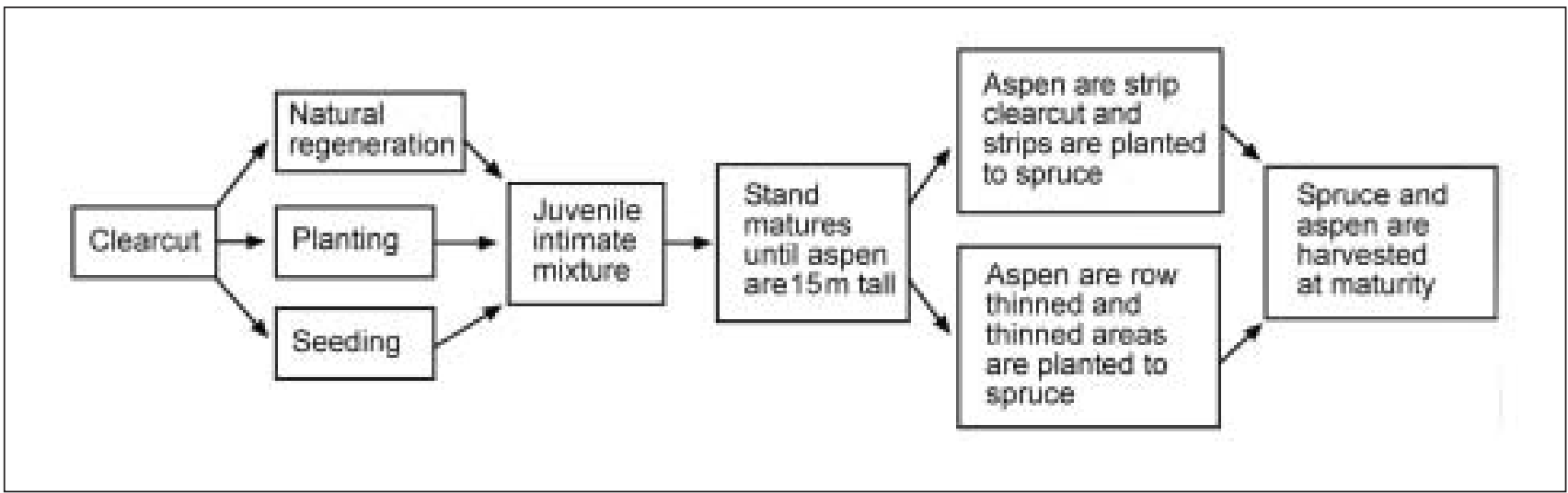

Fig. 4. Schematic diagram of the activities involved in the creation of horizontal and vertical stratification of spruce and aspen using strip clearcutting or row thinning.

(Zasada and Grigal 1978, Youngblood 1990). Using conventional logging equipment, uniform shelterwoods are more difficult to establish than strip shelterwoods.

Strip clearcutting and row thinning to create horizontal and vertical stratification of intimate mixtures

This approach is intermediate between the successional management and single-story management approaches in that clearcut sites are allowed to develop without intervention until aspen are about $15 \mathrm{~m}$ tall, which is approximately the minimum merchantable size for this species (Fig. 4). Partial aspen removal at that time using strip clearcutting or row thinning methods provides some economic return relatively early in the rotation as well as increasing light availability to understory spruce.
Strip clearcutting

Strip clearcutting is a variation of the strip shelterwood method. Narrow strips of aspen, of a width equivalent to about one-third the aspen height (i.e., about 4-5 m wide), are clearcut and planted with white spruce at densities of 1200-1600 stems/ha. Aspen will also regenerate in these narrow strips, but at relatively low densities because of the proximity of aspen in leave strips (Frey et al. 2003). Light availability in clearcut strips can be controlled to some extent by the strip orientation; models developed by Comeau and Bedford (2002) suggest that light availability in 5-m wide strips will be less than $20 \%$ unless they are oriented in a north-south direction. The abundance of aspen regeneration can be controlled, depending on objectives, by adjusting the width of the aspen leave strips on either side of the cut strip. Leaving total aspen 


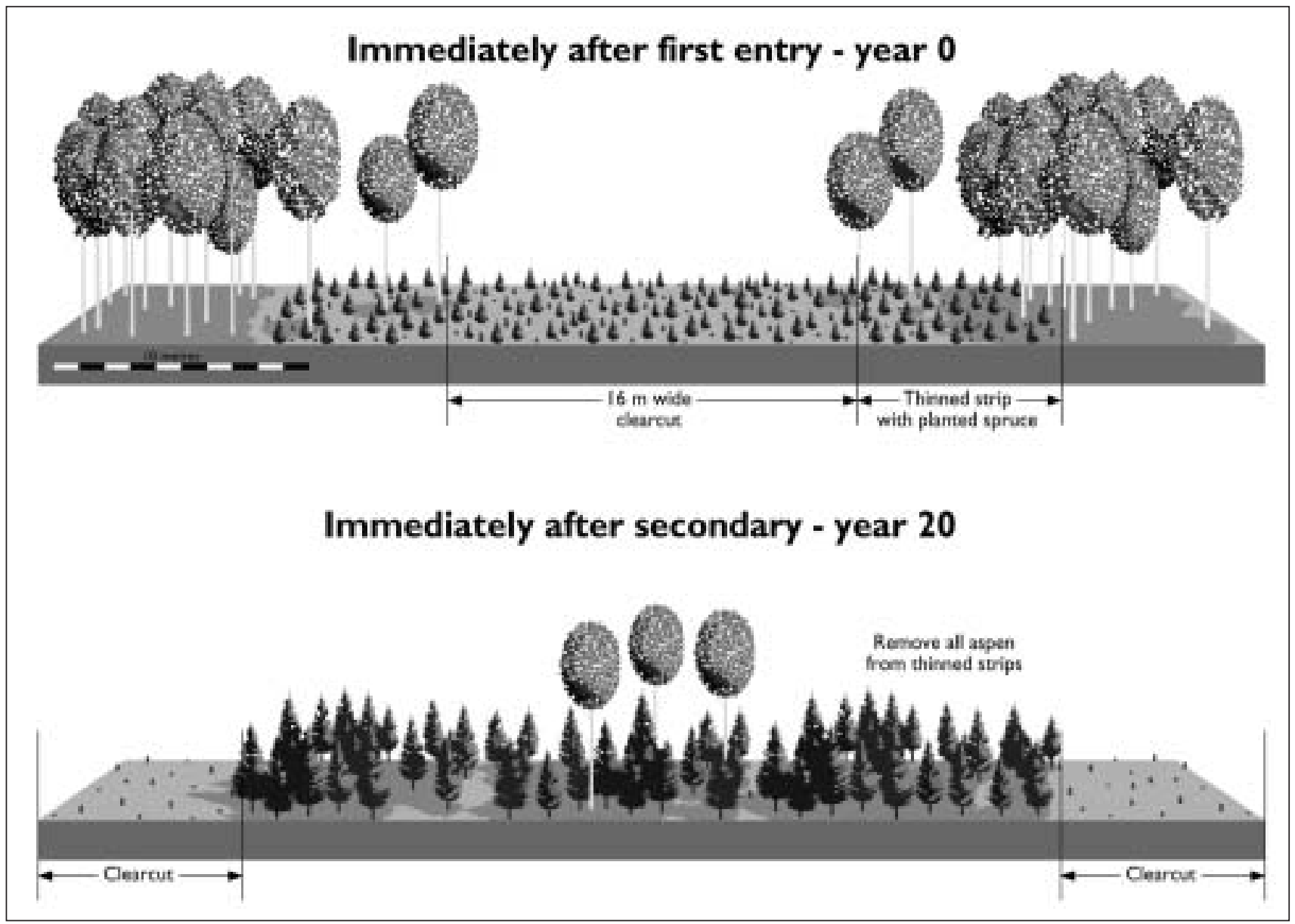

Fig. 5. An illustration of the effects of row thinning aspen 3 years after the first entry which took place when aspen were $15 \mathrm{~m}$ tall, and immediately after the second entry 20 years later.

basal area of $20 \mathrm{~m}^{2} / \mathrm{ha}$ across the site is expected to result in spruce-leading mixtures in the cut strips, whereas aspen basal area of $13 \mathrm{~m}^{2} /$ ha, because of the greater light availability, is expected to result in aspen-leading mixtures (Anon. 2002). Aspen in leave strips are harvested when white spruce in the mixture strips are approximately $4 \mathrm{~m}$ tall and are unlikely to lose co-dominance with aspen. Aspen is allowed to regenerate naturally in these strips and any advance spruce regeneration that was present in the understory of the aspen leave strips will also be released. Spruce and aspen are then harvested at maturity.

The advantage of this method over broadcast manipulation of aspen density is that post-planting costs are minimized because no tending activities are required. Whereas the broadcast method may require more than one non-commercial thinning entry, the strip method allows aspen to be harvested when it has some commercial value. The risk of hare damage may be greater in the strip than broadcast method, however, because of the proximity of dense aspen to newly planted areas.

\section{Row thinning}

This method is similar to strip clearcutting except that it involves three, rather than two, types of strips: a) aspen clearcut, b) aspen thinned, and c) aspen leave. It is an appropriate strategy for converting mature aspen stands to mixed- wood. Aspen are cut and skidded from extraction trails that are approximately $4 \mathrm{~m}$ wide. The feller-buncher then makes a second pass along the extraction trail, working to either side with its 8-m reach; to one side of the trail, all aspen are removed, and on the other side, aspen are thinned. The result is that aspen are clearcut in strips that are approximately $24 \mathrm{~m}$ wide (two times the 8-m reach of the feller-buncher plus two extraction trail widths) and thinned in 8-m wide strips to either side of the clearcut. The leave strip will likely be approximately $24 \mathrm{~m}$ wide. The clearcut/thinned strips alternate with aspen leave strips (Fig. 5). Aspen basal area of at least $20 \mathrm{~m}^{2} /$ ha should be retained within the thinned strips to control competing vegetation (Comeau et al. 2004). White spruce are planted in the clearcut strips and under the thinned aspen. When planted spruce are approximately $4 \mathrm{~m}$ tall (about 20 years old), aspen that were retained in the thinned and leave strips are harvested, taking care to protect understory spruce (e.g., Brace 1991). Spruce are harvested at maturity. Although this method involves two entries to remove aspen, there is an economic return at each entry because aspen is of merchantable size. Spruce planted in the thinned strips are also subject to the benefits associated with underplanting. As with strip clearcutting, this approach should be avoided on sites with abundant grass cover unless mechanical site preparation or herbicide treatments are planned. 


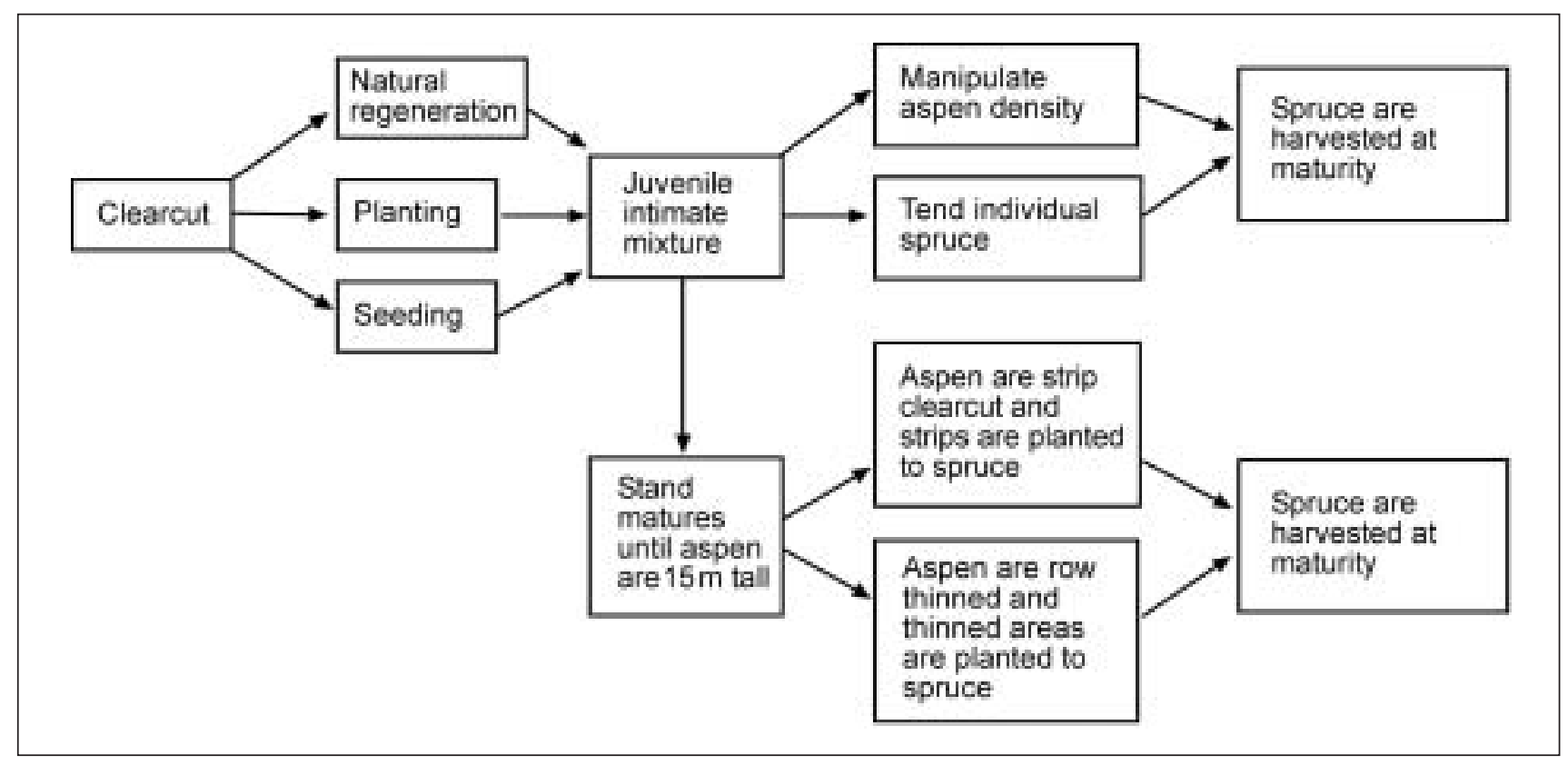

Fig. 6. Schematic diagram of the activities involved in single-story management of intimate mixtures.

Approach 2: Single-story management of intimate mixtures In this approach, rather than letting stands stratify into twostory mixtures, intimate mixtures are manipulated in various ways to achieve specific objectives for white spruce and aspen growth (Fig. 6). Single-story management of intimate mixtures sets the stage for a single harvest of spruce and aspen when merchantable volume objectives have been met. In general, single-story management requires multiple stand entries to apply treatments and to monitor stand development at appropriate intervals, and is more costly than two-story successional management where no silvicultural activities are required after spruce are established, or where aspen are not removed until they are of merchantable size. Single-story management of intimate mixtures is appropriate for stands that occur on productive sites that are also easily accessible. The intensity of management activities (i.e., the extent to which aspen are removed) and costs increase as the intended spruce yield increases. Managers should consider these options within the context of a long-term management plan, recognizing the contribution each species will make at harvest.

\section{Manipulating aspen density}

In this approach, aspen density and basal area are manipulated to provide adequate under- and within-canopy light availability to meet the following objectives for white spruce: a) good survival and early growth rates, b) rapid attainment of a co-dominant canopy position, and c) achievement of merchantable volume within the desired timeframe. Manipulating aspen density is an intensive, high-cost approach that is intended to lead to a single-cohort mixture, with the entire stand harvested at about age 80-90 years, and with both spruce and aspen contributing to merchantable volume. Alternatively, aspen could be removed in a commercial thinning at about age 60 years, followed by harvesting of spruce at maturity.
Silvicultural activities begin with the establishment of white spruce immediately following harvest of the previous stand. Site preparation and brushing treatments may be required to reduce vegetation competition and achieve full site occupancy by spruce. Light levels underneath wellstocked aspen stands can drop below 10\% between 10 and 25 years after establishment (Lieffers et al. 2002), and aspen removal treatments are carried out as necessary to maintain desired light availability at spruce height. If the objective is to allow white spruce to attain 70 and $80 \%$ of maximum diameter and height growth, respectively, 60\% light availability is required (Wright et al. 1998). In 10- to 40-year-old boreal aspen stands, $60 \%$ understory light availability can be achieved by reducing aspen basal area to $8 \mathrm{~m}^{2} /$ ha (Comeau 2002). It should be kept in mind, however, that vigour of grasses and other vegetation is best suppressed by maintaining light levels below 40\% (Lieffers and Stadt 1994). The first removal treatment should be carried out just before aspen basal area reaches that threshold, and repeat treatments will likely be necessary. The timing of treatments can be estimated using aspen growth models, in combination with regression models that predict under- and within-canopy light availability from easily measured aspen abundance variables such as basal area or quadratic mean diameter (Comeau 2002). Light availability increases rapidly with relative height in the aspen canopy, suggesting that greater aspen basal area can be retained once spruce have attained within-aspen canopy positions.

\section{Tending individual spruce}

In this approach, aspen are removed within specific radii of target spruce to increase light availability to spruce. Removal of the aspen overstory is well known to stimulate significant increases in spruce diameter and height (e.g., Lees 1966, Yang 1991, Lieffers and Stadt 1994, Groot 1999, Coopersmith and Hall 1999, Coopersmith et al. 2000). The intensive tending 


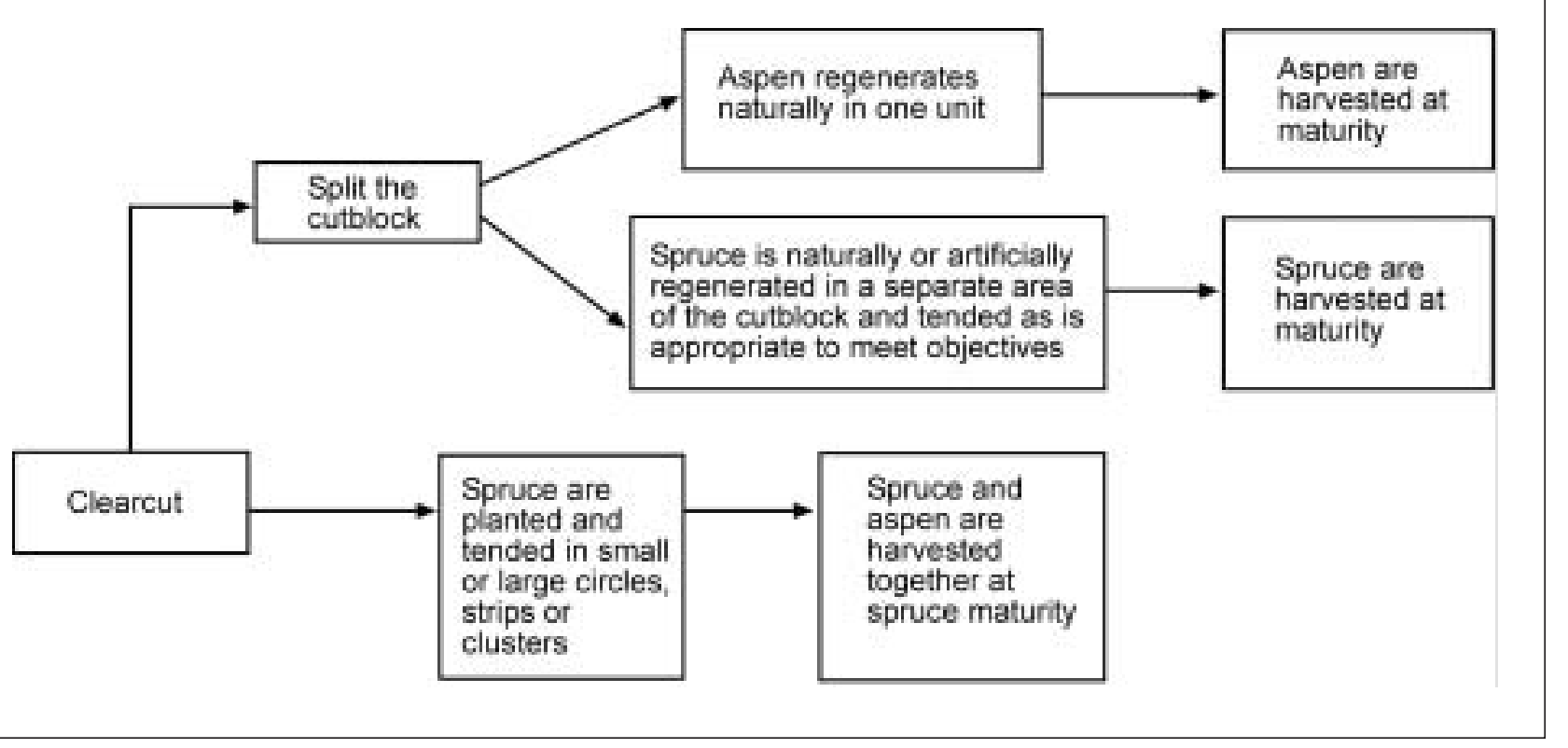

Fig. 7. Schematic diagram of the activities involved in "unmixing the mix" into descrete groupings of spruce and aspen.

associated with this management approach is highly effective for enhancing the performance and growth of white spruce within mixedwood stands, but is costly because the treatments are selective and ground-based (e.g., manual cutting with brushsaws or chainsaws, girdling, or selective herbicide treatments).

This approach has the advantage of facilitating long-term planning because white spruce and aspen are established in known proportions. Overall objectives for the stand will determine the desired ratio of spruce to aspen and the proportion of the stand to treat. Targets can be achieved by adjusting the number of spruce stems that are tended and the brushing radius. For example, if 400 spruce crop trees/ha are tended, treatment radii of 2 or $2.5 \mathrm{~m}$ will result in removal of aspen from $50 \%$ or $78 \%$ of the site, respectively. Mixedwoods with compositions ranging from deciduous leading to coniferous leading can be planned for and achieved through this process, and long-term yield predictions can be made.

The best time to apply brushing treatments will depend on stand-level objectives, but if the goal is to grow spruce as codominants with aspen, release treatments should be applied when stands are as young as four years old. Wood and von Althen (1993) suggest that each additional year spruce are overtopped by aspen can have a substantial negative effect on their growth rate. More than one manual cutting treatment will almost certainly be required at that stand age, especially on productive sites where aspen suckers grow vigorously (Fraser et al. 2002). The density and height of aspen suckers will, however, be tempered somewhat by the presence of surrounding aspen (e.g., Frey et al. 2003; Prévost and Pothier 2003; Comeau, unpublished data). Aspen may be removed in small (i.e., 0.5 to $1 \mathrm{~m}$ ) radii around spruce as early as the second year after planting, with larger radii treatments being applied when the height and crown width of aspen have increased. Fewer spruce stems need be targeted as the stand increases in age. It may also be necessary to combine early tending of individual spruce with later spacing of the remaining aspen, since the desired tending radius may increase to 5 $\mathrm{m}$ or greater in order to provide spruce with desired light levels at age 30 or 40 . Release treatments applied later in the stand life can still result in improved white spruce growth (e.g., Yang 1989), as long as trees are of adequate vigour to release (Ruel et al. 2000). However, delays in tending are likely to result in longer spruce rotations.

\section{Approach 3: "Unmixing the mix" into discrete groupings of spruce and aspen}

Management of intimate mixtures can be simplified by "unmixing the mix" into discrete, single-species groupings (Fig. 7). This can be accomplished by either splitting the cutblock into relatively large spruce and aspen units, or by creating small clusters, patches, or strips of spruce, aspen, and intimate mixtures of the two species. Single-species groupings occur naturally in mixedwood forests, often in gaps formed by small scale disturbances or the absence of natural aspen regeneration (Chen and Popadiouk 2002). They can be artificially created in managed mixedwood stands to increase structural complexity.

\section{Splitting the cutblock}

The simplest way to create discrete species units is by splitting a harvested cutblock and allocating one unit to aspen regeneration and a second unit to spruce regeneration. In the spruce unit, the necessary treatments are applied to meet spruce survival and growth objectives. This approach is appropriate for relatively inaccessible or unproductive sites where intensive stand tending is not cost-effective, and where the objective is to grow spruce and aspen components separately to meet timber supply requirements. Costs are relatively low because individual treatment units are large enough to accommodate the use of aerial herbicide treatments to control aspen in the spruce segments. 


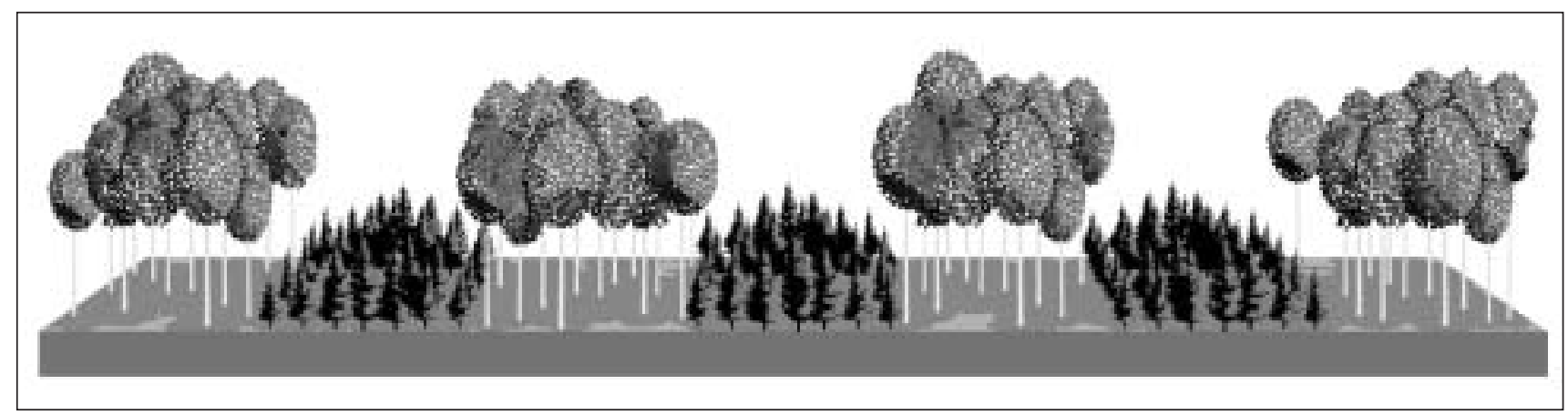

Fig. 8. An example of "unmixing the mix" into discrete strips of aspen and spruce early in stand development. In this example, spruce are tended in $20 \mathrm{~m}$ strips that alternate with $20 \mathrm{~m}$ strips of aspen. Spruce in the centre of the strips are taller because they receive more light than those next to the aspen.

Although the simplicity of splitting cutblocks makes it an attractive option, excessive reliance on this method will work against achieving biodiversity objectives. Planning for the density and distribution of split openings should be based on ecological, as well as economic, considerations because the advantages provided by mixedwoods may be lost if stand units are sufficiently large that spruce are growing more than a tree length from aspen.

Tending large circles, strips, or clusters of spruce within a mixedwood stand matrix

In this approach, white spruce are established in small patches and tended until they are out of danger of being overtopped by aspen. Applied to stands across the landscape, this approach allows for a range of possible distributions of aspen and spruce volume. On its own, it will not fully replicate the range of stand structures in natural mixedwoods; however, it is appropriate for use as part of a larger, landscape-level plan. The most suitable type, density, and distribution of groupings for a particular site will depend on overall objectives at both the stand- and landscape-levels, and on the natural distribution of aspen and spruce.

Management activities for these approaches begin immediately after the previous stand has been harvested. Regeneration costs tend to be relatively low because it is easy to plant in patches, but costs will increase if site preparation is necessary to establish white spruce and maximize early growth potential. Even where spruce is growing well, multiple brushing entries may be required to keep the spruce patches free of overtopping aspen. In general, ground-based brushing treatments are less expensive when they are applied in patches than on a broadcast basis because only a fraction of the total area is treated, but they are more expensive than broadcast aerial herbicide treatments. The patches of spruce are easy to locate during tending operations, which also reduces costs. Costs can be further reduced if patches are of sufficient size to allow herbicides to be applied aerially. This strategy is suitable for sites that are both productive and easily accessible, and where the objective is to create a codominant mixture of spruce and aspen that can be harvested at about age 80 or 90 .

The following configurations are examples of tending spruce in discrete small groupings:

- Large circular groupings of white spruce can be created by

brushing aspen in 20- to $25-\mathrm{m}$ radius circles and planting spruce seedlings in each circle. Distribution and density of the large circles will determine the relative proportions of spruce and aspen in the mixture.

- Alternating strips of white spruce and aspen can be established by planting spruce in linear strips and leaving unplanted strips between them (Fig. 8). Width of the strips, including the buffer zone, will determine the relative proportions of spruce and aspen in the mixture.

- Small clusters of six to 10 spruce trees can be planted along transects, with aspen allowed to regenerate between the clusters. Spacing of the clusters along the transects and the width of leave strips between the transects will determine the relative proportions of spruce and aspen.

Regardless of the configuration, it may be desirable to maintain an aspen-free zone around the patches or strips of white spruce to allow adequate light to meet spruce growth objectives. If desired, spruce may be planted across the entire gap, with reduced growth expected at the edges. Both density and height of surrounding aspen affect the distance over which they cast shade. According to Pritchard and Comeau (2004), spruce will receive at least $60 \%$ light at mid-crown as long as they are a distance away from surrounding aspen that is equivalent to one-half the difference between aspen height and the height to spruce mid-crown, and as long as light transmittance in the surrounding aspen stand is at least $20 \%$. On frost-prone sites, however, the risk of damage increases with patch size (Groot et al. 1997, Pritchard and Comeau 2004). During initial planning, the appropriate patch size can be determined using local knowledge about relative rates of height growth for spruce and aspen.

\section{Yield Implications for Different Mixedwood Scenarios}

Models for estimating yield of tended mixedwood stands are not fully developed at this time, so we cannot present reliable information regarding the yield implications for some of the more complex scenarios we have presented in this paper. The Mixedwood Growth Model (MGM2005A) (Bokalo 2005) can simulate some of the approaches we describe, but it has limited ability to address patch or strip treatments because it is currently distance-independent and non-spatial. This model also slightly overestimates the response of advance spruce regeneration to release (Craig Farnden, personal communication, 2003). MGM is driven largely by site index with growth 


\begin{tabular}{|c|c|c|c|c|c|}
\hline & & Rotation & & (m3/ha/ & ear) \\
\hline & enario $^{a}$ & (years) & spruce & Aspen & Total \\
\hline 1 & Pure aspen. & 60 & 0 & 3.8 & 3.8 \\
\hline 2 & $\begin{array}{l}\text { Pure white spruce with a minor component (200 stems/ha) } \\
\text { of aspen. }\end{array}$ & 90 & 3.2 & 0.7 & 3.9 \\
\hline 3 & $\begin{array}{l}\text { Mixedwood resulting from the planting of white spruce at } \\
1100 \text { stems/ha and no tending, followed by a single-stage harvest. }\end{array}$ & 90 & 0.7 & 2.2 & 2.9 \\
\hline 4 & $\begin{array}{l}\text { Patch mixture of } 50 \% \text { spruce and } 50 \% \text { aspen resulting from the } \\
\text { planting of white spruce at } 1100 \text { stems/ha, followed by tending } \\
\text { spruce in patches } 20 \text { to } 30 \mathrm{~m} \text { across, and leaving the remainder } \\
\text { of the block untended. }\end{array}$ & 90 & 1.1 & 1.0 & 2.2 \\
\hline 5 & $\begin{array}{l}\text { Mixedwood resulting from planting white spruce at } \\
1100 \text { stems/ha and thinning aspen to } 1100 \text { stems/ha at age } 5 \text { years. } \\
\text { This scenario approximates the manipulation of aspen density in } \\
\text { "Approach } 2 \text { - Single-story management of intimate mixtures." }\end{array}$ & 90 & 1.6 & 2.3 & 3.9 \\
\hline 6 & $\begin{array}{l}\text { Mixedwood resulting from allowing aspen to regenerate and } \\
\text { grow to age } 40 \text { years, at which time white spruce are underplanted } \\
\text { at } 1600 \text { stems/ha. Aspen are harvested at age } 60 \text { with understory } \\
\text { protection and a mixture of spruce and aspen are harvested at } \\
120 \text { years (spruce age } 80 \text { years). This scenario approximates the } \\
\text { use of underplanting we describe in "Approach } 1 \text { - Successional } \\
\text { management of two-story intimate mixtures." }\end{array}$ & 120 & 1.8 & 3.5 & 5.3 \\
\hline
\end{tabular}

a All simulations are for a site with white spruce $\mathrm{SI}_{50}=16 \mathrm{~m}$ and aspen $\mathrm{SI}_{50}=20 \mathrm{~m}$ and are started from age 10 . In scenarios $1,3,5$, and 6 , aspen density was 10000 stems/ha at age 10. Scenario 4 is calculated from Scenarios 2 and 3, based on the assumption that conifer yield is $45 \%$ of the value obtained in Scenario 2 . Merchantable volumes assume a minimum DBH of $12.5 \mathrm{~cm}$, a minimum top diameter of $7.5 \mathrm{~cm}$, and a stump height of $30 \mathrm{~cm}$. A $20 \%$ reduction in volume was included to account for variation in stocking and for other losses.

rates adjusted using various competition functions, and is currently being used for yield estimation in Alberta. MGM has been used to prepare estimates of yield for six scenarios in which yields for pure spruce and aspen stands are compared with yields from various mixtures that are as similar as possible to approaches we have discussed in this paper (Table 2). The results are expressed as mean annual increment (MAI) to accommodate differing rotation lengths. For these scenarios total MAI ranged from 2.6 to $5.3 \mathrm{~m}^{3} / \mathrm{ha}$ /year, but resulted in substantial ranges in coniferous and deciduous yield. The lowest MAI values were obtained from Scenarios 3 and 4. In Scenario 3, planting white spruce in a dense aspen stand resulted in only very small spruce yields after 90 years (61 $\mathrm{m}^{3} / \mathrm{ha}$ ), and waiting to age 90 resulted in substantial reductions in aspen yield. Splitting the block into patches of aspen and spruce and harvesting the stand at age 90 (at spruce culmination age) (Scenario 4) resulted in moderate spruce yields but low aspen yields due to delaying harvesting 30 years past culmination age for aspen. Thinning the aspen to 1100 stems/ha at age 5 (Scenario 5) resulted in spruce yields of 142 $\mathrm{m}^{3} /$ ha at age 90 , which is still substantially lower than the 289 $\mathrm{m}^{3} /$ ha spruce yield in the pure spruce plantation (Scenario 2). Underplanting (Scenario 6) provides the highest MAI of the scenarios tested, and reflects that both species were harvested at their respective culmination ages as a result of overlapping rotations for the two species.

\section{Issues Related To Policy and Planning}

Mixedwood stand management in British Columbia and Alberta is in the process of changing from being primarily focused on conifer management to being focused on mixed species management. Related policies are not yet well defined. Successful policy will require accountability, but should be flexible enough for managers to adjust stand-level plans in response to variation in early stand development (e.g., poor survival of plantations, poor establishment of aspen, etc.) as long as landscape-level objectives are met. Policies must also be adjusted to accept changes in dominant species resulting from harvest. This will allow conifer-dominated stands to regenerate to aspen-dominated, vertically stratified mixtures (or pure aspen stands) following clearcutting, and aspendominated stands to develop into conifer-dominated mixedwoods following understory protection harvesting. Information will be required to assist managers in developing plans that include a clear line of logic between landscape-level objectives and stand-level tactics. Accurate inventories, including characterization of understory densities, are required. Mechanisms will be needed to track stand development and monitor progress toward stand-level objectives, as well as to assess the potential effects of stand-level changes at the landscape-level. In order to accomplish this, reliable modeling tools are needed to predict growth and yield under different management and treatment scenarios. 
Policies should facilitate the application of timely and effective corrective action where objectives are not being met. Mechanisms for conflict resolution and improved cooperation are required where forest companies have overlapping licenses and conflicting objectives for softwoods and hardwoods in a particular management unit (MacDonald 1996). Short term benefits of integrated planning between license holders could potentially include reduced costs for road construction and maintenance, efficient utilization of harvested timber, and increased ability to reconcile ecological, economic, and social requirements. Over the long-term, the coordination of activities in mixedwood ecosystems will facilitate the achievement of forest-level objectives for biological diversity, soil conservation, and ecosystem function, which will benefit all stakeholders.

\section{Conclusions}

Successful management of boreal mixedwoods in northeastern British Columbia and Alberta requires the development of clear objectives and the concurrent application of a variety of approaches across the landscape. We have presented several different approaches that may be useful for creating different types of stands and stand structures in order to achieve different objectives. Some of these approaches are untested for western boreal mixedwoods and unexpected results can be anticipated. Costs must be considered in selecting appropriate options; due to the long rotation length in boreal forests and some of these options may be too expensive to apply in low productivity stands. Refinements in yield prediction are required as a basis for detailed planning and to evaluate the consequences of applying the available management options. Our current analysis suggests that various options may result in similar total volume yield, but that the relative contribution of the aspen and spruce components will vary. Results indicate that successional management of mixedwoods where aspen and spruce are harvested at ages 60 and 120 , respectively, has the potential to provide higher yields than other options.

\section{Acknowledgements}

We thank Lorne Bedford (Forest Practices Branch, B.C. Ministry of Forests) and Gitte Grover (Alberta-Pacific Forest Industries) for helping describe various management approaches, and for providing input during the development of a presentation that was subsequently incorporated into this paper. We also thank Frank McAllister (B.C. Timber Sales), Steve Blanton (Manning Diversified Forest Products Ltd., Manning), Dale Dunand (Weyerhaeuser, Grande Prairie), Wes Neumeier (Canfor, Chetwynd Division), and Greg Taylor (Canfor, Fort St. John Division) for supplying information about current silviculture costs.

\section{References}

Alfaro, R.I. 1996. Role of genetic resistance in managing ecosystems susceptible to white pine weevil. For. Chron. 72: 374-380.

Andison, D.W. and J.P. Kimmins. 1999. Scaling up to understand British Columbia's boreal mixedwoods. Environ. Rev. 7: 19-30.

Anon. 2000. Influence of growth rate on strength and related wood properties of boreal white spruce. Technote $00-08 \mathrm{~W}$, Forintek Canada, Vancouver, BC.

Anon. 2002. Silviculture practices in boreal mixedwood forests. Univ. of Northern B.C.
Anon. 2003. Silviculture guide to managing spruce, fir, birch, and aspen mixedwoods in Ontario's boreal forest. Ont. Min. Nat. Res., Version 1.

Beckingham, J.D. and J.H. Archibald. 1996. Field guide to ecosites of northern Alberta. Nat. Resour. Can., Can. For. Serv., North. For. Cent., Edmonton. Spec. Rep. 5.

Bokalo, M. 2005. Mixedwood Growth Model (MGM2005A). University of Alberta, Edmonton. Available at: http://www.rr2.ualberta.ca/Research/MGM/mgm.htm

Brace, L.G. 1991. Protecting understory white spruce when harvesting aspen. In A. Shortreid (ed.). Northern Mixedwood '89: Proceedings of a Symposium, Fort St. John, B.C. pp. 116-128. For. Can., Pacific For. Centre, Victoria, B.C., FRDA. Rep. 164.

Brace, L.G. and I.E. Bella. 1988. Understanding the understory: dilemma and opportunity. In R.D.

Adams (ed.). Aspen Symposium '89. Proc. Symp. July 25-27, 1989, Duluth, Minn. pp. 69-86. USDA. For. Serv. Gen. Tech. Rep. NC-140. Chen, H.Y.H. and R.V. Popadiouk. 2002. Dynamics of North American boreal mixedwoods. Environ. Rev. 10: 137-166.

Coates, K.D., S. Haeussler, S. Lindeburgh, R. Pojar and A.J. Stock. 1994. Ecology and silviculture of interior spruce in British Columbia. For. Can., B.C. Min. For., Victoria, B.C. FRDA Rep. 220. Comeau, P.G. 1996. Why Mixedwoods? In P.G. Comeau and K.D. Thomas (Eds.). Silviculture of temperate and boreal broadleafconifer mixtures. pp. 1-5. B.C. Min. For., Land Manage. Handb. 36. Victoria, B.C.

Comeau, P.G. 2002. Relationships between stand parameters and understory light in boreal aspen stands. B.C. Journal of Ecosystems and Management 1(2):103-110.

Comeau, P.G. and L. Bedford. 2002. Light under and adjacent to aspen stands and implications for growing spruce. In Popular Summaries, Fourth International Forest Vegetation Management Conference, Nancy, France, June 17-21, 2002. pp. 177-179.

Comeau, P.G., C.N. Filipescu, R. Kabzems and C. DeLong. 2004. Early growth of white spruce underplanted beneath spaced and unspaced aspen stands in northeastern B.C. Can. J. For. Res. 34: 2277-2283.

Constabel, A.J. and V.J. Lieffers. 1996. Seasonal patterns of light transmission through boreal mixedwood canopies. Can. J. For. Res. 26: $1008-1014$.

Coopersmith, D. and E. Hall. 1999. Experimental project 1077 - The Siphon Creek mixedwood trial: The use of a simple HDR to predict the growth success of planted white spruce seedlings beneath aspen canopies. B.C. Min. For., Prince George For. Reg. Res. Note No. PG17.

Coopersmith, D. B. Sagar and D. Thompson. 2000. Ten year results of the Bear Mountain mixedwood trial (EP1077): The effect of overtopping aspen canopies on white spruce seedling growth and seedling microclimate. B.C. Min. For., Prince George For. Reg. Res. Note No. PG-23.

Côté, M., J. Ferron and R. Gagnon. 2003. Impact of seed and seedling predation by small rodents on early regeneration establishment of black spruce. Can. J. For. Res. 33: 2362-2371.

DeLong, C. 1997. Operational considerations for underplanting hardwood stands with white spruce. B.C. Min. for., Prince George Forest Region, Prince George, B.C., Note No. PG-11.

DeLong, C. 2000. Planting white spruce under trembling aspen: 7year results of seedling condition and performance. Res. Br., B.C. Min. For., Victoria, B.C. Work. Pap 54. Available at: http://www.for.gov.bc.ca/hfd/pubs/Docs/Wp/Wp54.htm

DeLong, C., V.J. Lieffers and P.V. Blennis. 1997. Microsite effects on first-year establishment and overwinter survival of white spruce in aspen-dominated boreal mixedwoods. Can. J. For. Res. 27: 1452-1457.

DeLong, C., A. MacKinnon and L. Jang. 1990. A field guide for identification of ecosystems of the north-east portion of the Prince George Forest Region. B.C. Min. For., Victoria, BC. 
Densmore, R.V., G.P. Juday and J.C. Zasada. 1999. Regeneration alternatives for upland white spruce after burning and logging in interior Alaska. Can. J. For. Res. 29: 413-423.

Flesch, T.K. and J.D. Wilson. 1999. Wind and remnant tree sway in forest cutblocks. II. Relating measured tree sway to wind statistics. Agric. For. Meteorology 93: 243-258.

Fraser, E.C., V.J. Lieffers, S.M. Landhäusser and B.R. Frey. 2002. Soil nutrition and temperature as drivers of root suckering in trembling aspen. Can. J. For. Res. 32: 1685-1691.

Frey, B.R., V.J. Lieffers, A.D. Munson and P.V. Blenis. 2003. The influence of partial harvesting and forest floor disturbance on nutrient availability and understory vegetation in boreal mixedwoods. Can. J. For. Res. 33: 1180-1188.

Galipeau, C., D. Kneeshaw and Y. Bergeron. 1997. White spruce and balsam fir colonization of a site in the southeastern boreal forest as observed 68 years after fire. Can. J. For. Res. 27: 139-147.

Gerlach, J.P., P.B. Reich, K. Puettmann and T. Baker. 1997. Species, diversity, and density affect tree seedling mortality from Armillaria root rot. Can. J. For. Res. 27: 1509-1512.

Greene, D.F., J.C. Zasada, L. Sirois, D. Kneeshaw, H. Morin, I. Charron and M.J. Simard. 1999. A review of the regeneration dynamics of North American boreal forest tree species. Can. J. For. Res. 29: 824-839.

Greene, D.F., D. Kneeshaw, C. Messier, V. Lieffers, D. Cormier, R. Doucet, K.D. Coates, A. Groot, G. Grover and C. Calogeropoulos. 2002. Modelling silvicultural alternatives for conifer regeneration in boreal mixedwood stands (aspen/white spruce/balsam fir). For. Chron. 78: 281-295.

Groot, A. 1999. Effects of shelter and competition on the early growth of planted white spruce (Picea glauca). Can. J. For. Res. 29: 1002-1014.

Groot, A. and D.W. Carlson. 1996. Influence of shelter on night temperatures, frost damage, and bud break of white spruce seedlings. Can. J. For. Res. 26: 1531-1538.

Groot, A, D.W. Carlson, R.L. Fleming and J.E. Wood. 1997. Small openings in trembling aspen forest: microclimate and regeneration of white spruce and trembling aspen. NODA/NP Tech. Rep. TR-47. $25 \mathrm{p}$.

Johnson, H.J. 1986. The release of white spruce from trembling aspen overstoreys. A review of available information and silvicultural guidelines. Man. Dep. of Nat. Res., For. Br.

Kabzems, R. 2001. Regenerating boreal mixedwoods: 3-year results of a group shelterwood silviculture system in trembling aspen-white spruce stands. B.C. Min. For. Prince George For. Reg. Note - PG-24. Kabzems, R. and O. Garcia. 2004. Structure and dynamics of trembling aspen - white spruce mixed stands near Fort Nelson, B.C. Can. J. For. Res. 34: 384-395.

Kobe, R.K. and K.D. Coates. 1997. Models of sapling mortality as a function of growth to characterize interspecific variation in shade tolerance of eight tree species of northwestern British Columbia. Can. J. For. Res. 27: 227-236.

Krasowski, M. 1996. Measures to reduce overwinter injury to planted spruce in the boreal forest of British Columbia. For. Can. and B.C. Min. For., Victoria, B.C. FRDA Rep. No. 254.

Lees, J.C. 1964. A test of harvest cutting methods in Alberta's spruceaspen forest. Can. Dept. For. Res., For. Branch, Ottawa, Ont. Publ. No. 1042.19 p.

Lees, J.C. 1966. Release of white spruce from aspen competition in Alberta's spruce-aspen forest. Can. Dept. For. Res., For. Branch, Ottawa, Ont. Publ. No. 1274. 14 p.

Lieffers, V.J., R.B. Macmillan, D. MacPherson, K. Branter and J.D. Stewart. 1996. Semi-natural and intensive silvicultural systems for the boreal mixedwood forest. For. Chron. 72: 286-292.

Lieffers, V.J., C. Messier, P.J. Burton, J-C. Ruel and R.E. Grover. 2003. Nature-based silviculture for sustaining a variety of boreal forest values. In P.J. Burton, C. Messier, D.W. Smith and W.L. Adamowicz (eds.).Towards Sustainable Management of the Boreal Forest, Chapter 13, NRC Research Press, Ottawa.
Lieffers, V.J., B. Pinno and K. Stadt. 2002. Light dynamics and freeto-grow standards in aspen-dominated mixedwood forests. For. Chron. 78: 137-145.

Lieffers, V.J. and K. Stadt. 1994. Growth of understory Picea glauca, Calamagrostis canadensis and Epilobium angustifolium in relation to overstory light. Can. J. For. Res. 24: 1193-1198.

MacDonald, G.B. 1996. Mixedwood management research and practice in Ontario. In P.G. Comeau and K.D. Thomas (eds.). Silviculture of temperate and boreal broadleaf-conifer mixtures. pp. 102-113. B.C. Min. For., Land Manage. Handb. 36. Victoria, B.C.

MacDonald, G.B., M.L. Cherry and D.J. Thompson. 2004. Effects of harvest intensity on development of natural regeneration and shrubs in an Ontario boreal mixedwood stand. For. Ecol. and Manage. 189: 207-222.

MacLean, D.A. 1996. Forest management strategies to reduce spruce budworm damage in the Fundy Model Forest. For. Chron. 72: 399-405.

MacPherson, D.M., V.J. Lieffers and P.V. Blenis. 2001. Productivity of aspen stands with and without a spruce understory in Alberta's boreal mixedwood forests. For. Chron. 77: 351-356.

Man, R. and V.J. Lieffers. 1999. Are mixtures of aspen and white spruce more productive than single species stands? For. Chron. 75 (3): 505-513.

Morrison, D., H. Merler and D. Norris. 1991. Detection, recognition and management of Armillaria and Phellinus root diseases in the southern interior of British Columbia. For. Can. and B.C. Min. For. FRDA Rep. No. 179, Victoria, B.C.

Navratil, S. 1996. Silvicultural systems for managing deciduous and mixedwood stands with white spruce understory. In P.G. Comeau and K.D. Thomas (eds.). Silviculture of temperate and boreal broadleaf-conifer mixtures. pp. 35-46. B.C. Min. For., Land Manage. Handb. 36. Victoria, B.C.

Navratil, S., L.G. Brace, E.A. Sauder and S. Lux. 1994. Silvicultural options to favor immature white spruce and aspen regeneration in boreal mixedwoods. Can. For. Serv., Edmonton. Information Rep. NOR-X-337.

Pankuch, J.M., P.V. Blennis, V.J. Lieffers and K.I. Mallett. 2003. Fungal colonization of aspen roots following mechanical site preparation. Can. J. For. Res. 33: 2372-2379.

Pastor, J. 1990. Nutrient cycling in aspen ecosystems. In Aspen Symp. Proc. 1989. U.S. Dep. Agric. For. Serv., St. Paul, Minn. Gen. Tech. rep. NC-140.

Peterson, E.B. and N. M. Peterson. 1995. Aspen managers' handbook for British Columbia. For. Can. and B.C. Min. For. FRDA Rep. No. 230.

Prévost, M. and D. Pothier. 2003. Partial cuts in a trembling aspen conifer stand: effects on microenvironmental conditions and regeneration dynamics. Can. J. For. Res. 33: 1-15.

Pritchard, J.M. and P.G. Comeau. 2004. Effects of opening size and stand characteristics on light transmittance and temperature under young trembling aspen stands. For. Ecol. Manage. 200: 119-128

Radvanyi, A. 1987. Snowshoe hares and forest plantations: a literature review and problem analysis. For. Can., Edmonton, AB. Inf. Rep. NOR-X-290.

Reynolds, R.D. 1999. A cost evaluation of three direct-seeding systems for jack pine in Eastern Canada. FERIC Technical Note TN281, Vancouver, B.C.

Rowe, J.S. 1972. Forest regions of Canada. Dept. of Environment. Can. For. Serv. Publ. 1300.

Ruel, J.C., C. Messier, R. Doucet, Y. Claveau and P. Comeau. 2000. Morphological indicators of growth response of coniferous advance regeneration to overstorey removal in the boreal forest. For. Chron. 76(4): 633-642.

Smith, D.M., B.C. Larson, M.J. Kelty and P.M.S. Ashton. 1997. The Practice of Silviculture: Applied Forest Ecology, John Wiley and Sons, Inc. New York.

Stathers, R.J. 1989. Summer frost in young forest plantations. B.C. Min. For. and For. Can., Victoria, B.C. FRDA Rep. No. 73. 
Stewart, J.D., K.J. Stadt and V.J. Lieffers. 2000. Regeneration of white spruce under aspen canopies: seeding, planting, and site preparation. West. J. Appl. For. 15(4): 177-182.

Stiell, W.M. and A.B. Berry. 1985. Limiting white pine weevil attacks by side shade. For. Chron. 61: 5-9.

Su, Q., D.A. MacLean and T.D. Needham. 1996. The influence of hardwood content on balsam fir defoliation by spruce budworm. Can. J. For. Res. 26: 1620-1628.

Taylor, S.P., R.I. Alfaro, C. DeLong and L. Rankin. 1996. The effects of overstory shading on white pine weevil damage to white spruce and its effect on spruce growth rates. Can. J. For. Res. 26: 306-312.

Waldron, R.M. and V.S. Kolabinski. 1994. Uniform shelterwood cutting and scarifying in white spruce-trembling aspen stands to induce natural white spruce regeneration, Manitoba and Saskatchewan. Nat. Res. Can., Can. For. Serv., Winnipeg, Man. Can. Man. Partnership Agreement in Forestry.

Welham, C., B. Seely and H. Kimmins. 2002. The utility of the twopass harvesting system: an analysis using the ecosystem simulation model FORECAST. Can. J. For. Res. 32: 1071-1079.

Wood, J.E. and F.W. von Althen. 1993. Establishment of white spruce and black spruce in boreal Ontario: Effects of chemical site preparation and post-planting weed control. For. Chron. 69: 554-560.

Wright, E.F., K.D. Coates, C.D. Canham and P. Bartemucci. 1998. Species variability in growth response to light across climatic regions in northwestern British Columbia. Can. J. For. Res. 28:871-886.

Yang, R.C. 1989. Growth of white spruce following release from trembling aspen. For. Can. North. For. Cent. Inf. Rep. NOR-X-302.

Yang, R.C. 1991. Growth of white spruce following release from aspen competition: 35 year results. For. Chron. 67: 706-711.

Youngblood, A.P. 1990. Effect of shelterwood removal methods on established regeneration in an Alaska white spruce stand. Can J. For. Res. 20: 1378-1381.

Zasada, J.C. and D.F. Grigal. 1978. The effects of silvicultural system and seed bed preparation on natural regeneration of white spruce and associated species in interior Alaska. In C.A. Hollis and A.E. Squillace (eds.). Proceedings: fifth North American Forest Biology Workshop, 13-15 Mar. 1978, Gainesville, FL. pp. 213-220. School of Forest Resources and Conservation, University of Florida, Gainesville. 